2016-11-30

\title{
Ice-flow and meltwater landform assemblages in the Gulf of Bothnia
}

\section{Greenwood, SL}

http://hdl.handle.net/10026.1/8439

10.1144/M46.163

Geological Society, London, Memoirs

All content in PEARL is protected by copyright law. Author manuscripts are made available in accordance with publisher policies. Please cite only the published version using the details provided on the item record or document. In the absence of an open licence (e.g. Creative Commons), permissions for further reuse of content should be sought from the publisher or author. 


\title{
Ice-flow and meltwater landform assemblages in the Gulf of Bothnia
}

\author{
S. L. GREENWOOD ${ }^{1 *}$, C. C. CLASON ${ }^{2} \&$ M. JAKOBSSON \\ ${ }^{1}$ Department of Geological Sciences, Stockholm University, Svante Arrhenius väg 8, 10691 Stockholm, Sweden \\ ${ }^{2}$ Department of Physical Geography, Stockholm University, Svante Arrhenius väg 8, 10691 Stockholm, Sweden \\ *Corresponding author (e-mail: sarah.greenwood@geo.su.se)
}

The Gulf of Bothnia is a shallow, elongate basin dividing Sweden and Finland, and is located in the centre of the terrain formerly occupied by the Fennoscandian Ice Sheet (FIS). It is considered to have hosted a variety of different glaci-dynamic environments during the evolution of the FIS, but direct glacial geological or geomorphological evidence from the Gulf itself is almost entirely lacking. Recent acquisition of high-resolution multibeam data enables direct investigation of the basin for the first time. These data reveal a wealth of glacial landforms in the Gulf of Bothnia, including glacial lineations, ribbed moraine, eskers, meltwater channels, moraines, crevasse-squeeze ridges and iceberg ploughmarks with a variety of different morphologies. Distinct landform assemblages record multiple ice-flow events or phases of differing glaci-dynamic character. Two contrasting glacial landform assemblages are presented from the western and northern Bothnian Sea.

\section{Description}

Assemblage 1, located in the western Bothnian Sea (Fig. 1), comprises an $80 \mathrm{~km}$-long field of approximately 950 pronounced, elongate and aligned hills (Jakobsson et al. 2016) These mounds have a typical length of about $900 \mathrm{~m}$, width $\sim 300 \mathrm{~m}$ and amplitude $\sim 6 \mathrm{~m}$, and are formed in glacial till, often clustered locally with multiple individuals formed in/of a single till patch. Many mounds, however, appear to be bedrock-cored, with preferential till accumulation over bedrock obstacles (Fig. 1e). Within this population, the mounds show a progressive downstream elongation. Overall, they possess a SSE orientation, with some slight southward shifting in the downstream and western parts of the assemblage. The SSE-orientated features are cross-cut and terminated at their downstream end by a SW-orientated group of much narrower $(<50 \mathrm{~m})$, lower amplitude $(\sim 1-4 \mathrm{~m})$ and elongate lineations (Fig. 1h). A well-developed channelised landform system weaves southward through the streamlined hills (Greenwood et al. 2016, Fig. 1f). These landforms comprise both incised channel forms and positive-relief ridges of comparable scale. The system evolves from small stream-like forms in the north (e.g. $\sim 30-50 \mathrm{~m}$ width, $\sim 1-2 \mathrm{~m}$ incised depth), through moderately-sized and interconnected channel-ridge segments, to large sinuous and connected ridges (e.g. $\sim 150 \mathrm{~m}$ width, $\sim 15 \mathrm{~m}$ amplitude) at the distal, south-eastern end of the system. In the north, the small channels occupy the troughs between streamlined mounds, while downstream the larger channel components ride over and incise through the hills. At the far northern end of the assemblage, low-amplitude transverse ridges (WSW-ENE, Fig. 1d) are superimposed upon the southward-directed landforms. Such transverse forms are absent from the rest of the assemblage area. Postglacial sedimentation has preferentially filled the lower-lying troughs of Assemblage 1, leaving minimal to no drape on landform crests.

Assemblage 2, in the northern Bothnian Sea (Fig. 1c), is similar in size to Assemblage 1, but is defined predominantly by a striking swarm of highly elongate and internally parallel lineations (Greenwood et al. 2015, Fig. 2). These lineations trend first SW, then S in the distal part of the assemblage, and have lengths up to $14 \mathrm{~km}$, the longest of which are located in the centre of the assemblage (Fig. 2b). Laterally and towards the head of the swarm, lineations transition to shorter and wider aligned hills (Fig. 2c), while they display an increase in their length downstream to the S (Fig. 2d). This lineation assemblage has been clearly traced back onto land, using terrestrial LiDAR elevation data and side-scan sonar images in the nearshore area. Incised channels are also widely present in Assemblage 2, but the channelised system contrasts markedly with that in the western assemblage. This system comprises both erosional and depositional landform elements, but these are disorganised and without any systematic trend or evolution. Channels are $0.5-4 \mathrm{~km}$ wide and up to $\sim 85 \mathrm{~m}$ deep, whereas a glacifluvial deposit, subsequently incised and partially eroded, measures $\sim 3 \mathrm{~km}$ by $\sim 4.5$ $\mathrm{km}$ (Fig. 2e). The largest erosional corridor is floored with glacifluvial sediments and lined with a sinuous ridge deposit, alongside which are numerous irregular depressions approximately $200 \mathrm{~m}$ wide and $10-20 \mathrm{~m}$ deep (Fig. 2f). These wide, incised corridors cut obliquely (SE) through the lineation field. Similarly to the western Bothnian Sea, there are few signs of any transverse ridges which overprint the main, southward-orientated landforms, although terrestrial data just north of our offshore assemblage reveal widespread metre-amplitude ridges which are transverse to the trend of the seaward-flowing lineations.

\section{Interpretation}

Both assemblages described here comprise elongate sedimentary landforms, interpreted as ice-flow directed drumlins and mega-scale glacial lineations (MSGLs), interwoven with a network of channelised forms comprising subglacial meltwater channels and eskers. However, Assemblages 1 and 2 differ markedly in the form and internal arrangement of these landforms, leading to contrasting palaeo-ice dynamic and palaeo-hydrological interpretations.

Assemblage 1 is dominated by a drumlin-field overprinted by a glacifluvial landform network (Fig. 1). Drumlins are usually interpreted as indicators of warm-based ice-sheet flow. The increasing downstream elongation of drumlins in Assemblage 1 points to an acceleration of the overriding ice (cf. Hart 1999; Stokes \& Clark 2002), which flowed from the southern part of the Swedish High Coast towards the southern exit of the Gulf of Bothnia. The accompanying meltwater landform system also displays a progressive evolution of form, from small streams, through interconnected channels and eskers, to increasingly large eskers (Fig. 1b, f). The glacial hydrological network was therefore well-connected, appears to represent a coherent system, and its flow direction is approximately aligned with that of the drumlins. Since the meltwater channels incise and eskers overprint drumlins (Fig. 1f), the geomorphological development of the meltwater landforms must post-date cessation of drumlin shaping, either immediately upon stabilisation of a deforming substrate, or at a later stage of ice flow adhering more or less to the earlier flow direction. The simpler interpretation is the former: that the drumlins and meltwater landforms represent the same phase of ice flow, and that the meltwater landforms are the final geomorphic imprint of this episode. The systematic downstream development of the meltwater landforms, and the absence of moraines or obvious glacifluvial fans throughout most of the length of the assemblage, suggests that this group of meltwater landforms may reflect a single, operational hydrological system rather than one which has developed incrementally by headward extension during ice retreat. The length of the interpreted channelised and connected meltwater system $(\sim 50-60 \mathrm{~km})$ is towards the upper limit of what may be considered physically plausible (e.g. 


\section{S. L. GREENWOOD, C.C. CLASON, M. JAKOBSSON}

Chandler et al. 2013), and suggests a high and sustained meltwater-discharge regime.

The sequence of events for Assemblage 1 in the western Bothnian Sea is interpreted as follows (Fig. 1g): (i) drumlinisation of a mobile subglacial sediment layer that became anchored on bedrock knobs, under ice of a moderate flow velocity that increased downstream to a margin position some distance beyond our assemblage; (ii) meltwater-landform development shortly thereafter, and potentially the cause for, the cessation of drumlinisation as subglacial meltwater conduits became an efficient mode of meltwater drainage and sediment consequently stiffened; (iii) retreat of the ice margin across the assemblage without pause, the margin only beginning to deposit retreat moraines as it approached the headward extent of the assemblage (e.g. Fig. 1d), towards the higher topography and crystalline bedrock of the present land and nearshore areas; (iv) at some stage, the timing as yet unknown, the southern end of the assemblage is cross-cut from the NE by a second, independent set of glacial lineations. While it is likely that Assemblage 1 formed in a deglacial sequence, it was not the final ice flow event to occur in the central-southern Bothnian Sea.

Assemblage 2, dominated by MSGLs and erosional meltwater landforms an order of magnitude larger than in Assemblage 1, represents a different dynamic setting. The downstream elongation of MSGLs and, in the north of the assemblage, their lateral transition to drumlins are interpreted by Greenwood et al. (2015) to mark the onset zone or upper tributary of a Bothnian Sea ice stream. The upper trunk width is approximately $40 \mathrm{~km}$, and both the lateral transition to less elongate forms and the non-ice streaming environment recorded by Assemblage 1 indicate that this ice stream did not occupy the whole basin. Onshore extension of Assemblage 2 indicates a supply of ice from northern Sweden (Fig. 2b, g). Flow was initially directed SSE but, immediately offshore from the present-day coast, swung abruptly SSW along the coastline before turning southward into the central Bothnian Sea. The glacifluvial elements of Assemblage 2 are less closely tied to the bedforms than in Assemblage 1. There is no systematic arrangement of meltwater landforms, which instead cut through the lineation assemblage in various directions. The size of the large meltwater corridor suggests a high-energy and high-discharge system, and/or a long-term (multiple glaciation?) avenue for meltwater routing. Sediment stratigraphy suggests the former interpretation (although the two are not mutually exclusive): the eastern flank of the corridor is pinned on a bedrock step, but the western flank is unconstrained by bedrock and the corridor cuts through both the most recent till and the sediments below (Fig. 2e). The corridor morphology therefore is taken to indicate a large erosive capacity. It is likely that retreat from this corridor was rapid; we tentatively interpret the depressions alongside the esker as kettle holes formed by abandoned blocks of ice (Fig. 2f). Comparable kettle-esker relationships are observed widely on land in Sweden in similarly sized glacifluvial corridors. At the head of the corridor, a large, irregular glacifluvial deposit (Fig. 2e) suggests a sudden dump of sediment, possibly corresponding to a subglacial conduit terminating at a grounding-line.

We interpret the following sequence of events for Assemblage 2 in the northern Bothnian Sea (Fig. 2): (i) onset of ice streaming, which diverted ice flowing off the Swedish coast from its SSE trajectory into the north-western and central Bothnian Sea, towards a distal margin position; (ii) cessation of streaming, leaving a pristine bedform imprint during rapid retreat without pause of the ice margin; (iii) retreat accompanied by (driven by?) rapid melting of the ice surface, which provided extremely high volumes of meltwater to be discharged subglacially in high energy, erosive and topologically chaotic corridors. The retreating ice margin probably stabilized close to the present-day coast, where De Geer moraines become widespread in the modern terrestrial realm.

\section{Discussion}

The landform composition of both assemblages leads to their interpretation as belonging to the retreat phase of the FIS through the Gulf of Bothnia. The conventional deglaciation pattern for the Finnish-Swedish sector of the FIS depicts a series of south-easterly directed lobes crossing the Gulf of Bothnia and splaying across the low relief of Finland (Punkari 1980; Johansson et al. 2011). Whereas Assemblage 1 could correspond to the so-called Baltic Sea lobe, Assemblage 2 is wholly inconsistent with this configuration. Greenwood et al. (2015) favour an interpretation of a late-stage icestream event, which was short-lived and rapid, and indicates a brief reconfiguration of the ice-sheet flow structure. Such a reconfiguration is also recorded in the overprinting of Assemblage 1 at its distal end by a group of elongate, spindle-like lineations. The timeframe for ice-sheet retreat throughout the full Gulf of Bothnia is suggested to be limited to about 1 kyr (Hughes et al. 2016; Stroeven et al. in press). To fit this, any events reconstructed within the Bothnian Sea must be rapid and retreat highly dynamic. Full data coverage of the Gulf of Bothnia is required to assess the relationship in both space and time between the two landform assemblages reported here and the wider, terrestrial deglaciation sequence.

Ice-flow behaviour in the Gulf of Bothnia is demonstrably non-uniform and spatially variable. The ice stream recorded by Assemblage 2 is limited to a width of approximately $40 \mathrm{~km}$, and Assemblage 1 reveals that more moderate ice-sheet velocities occupied the western parts of the basin. The ice stream does not follow the larger-scale bathymetry closely; it crosses the head of the trough that defines the eastern side of the Bothnian Sea. Ice flow in this marine basin is, therefore, governed by a varied set of controls. This is further attested by the composition of the landform assemblages. Drumlins, eskers and meltwater channels are more typical of terrestrial ice-sheet landscapes than continental-shelf marine environments. Marine areas are, on the contrary, usually characterised by highly elongate lineations indicative of ice streaming, and a subglacial hydrological system in which meltwater delivery is often ascribed to porewater flow through an unconsolidated sedimentary substrate (e.g. Ó Cofaigh et al, 2002; Wellner et al. 2006). Landform assemblages in the Gulf of Bothnia caution us therefore against treating all marine ice-sheet sectors in the same way, or expecting a similar set of controls upon marine ice-sheet dynamics. We hypothesise that surface melting was a strong control on deglacial dynamics in the Bothnian Sea and may have been a stronger control than iceberg calving as a form of ablation and driver of deglaciation.

\section{References}

CHANDLER, D.M., WADHAM, J.L. et al. 2013. Evolution of the subglacial drainage system beneath the Greenland Ice Sheet revealed by tracers. Nature Geoscience 6, 195-198.

GREENWOOD, S.L., CLASON, C.C., MIKKO, H., NYBERG, J., PETERSON, G. \& SMITH, C.A. 2015. Integrated use of LiDAR and multibeam bathymetry reveals onset of ice streaming in the northern Bothnian Sea. GFF 137, 284-292

GREENWOOD, S.L., JAKOBSSON, M., HELL, B. \& ÖIÅS, H. 2016. Esker systems in the Gulf of Bothnia. In DOWDESWELL, J.A., CANALS, M., JAKOBSSON, M., TODD, B.J., DOWDESWELL, E.K. \& HOGAN, K.A. (Eds). Atlas of Submarine Glacial Landforms: Modern, Quaternary and Ancient. Geological Society, London, Memoirs 46.

HART, J.K. 1999. Identifying fast ice flow from landform assemblages in the geological record: a discussion. Annals of Glaciology $\mathbf{2 8 ,} 59-67$.

HUGHES, A.L.C., GYLLENCREUTZ, R., LOHNE, Ø.S., MANGERUD, J. \& SVENDSEN, J.I. 2016. The last Eurasian ice sheets - chronological database and timeslice reconstruction. Boreas $\mathbf{4 5}, 1-45$.

JAKOBSSON, M., GREENWOOD, S.L., HELL, B. \& ÖIÅS, H. 2016. Drumlins in the Gulf of Bothnia. In DOWDESWELL, J.A., CANALS, M., JAKOBSSON, M.,

TODD, B.J., DOWDESWELL, E.K. \& HOGAN, K.A. (Eds). Atlas of Submarine Glacial Landforms: Modern, Quaternary and Ancient. Geological Society, London, Memoirs 46.

JOHANSSON, P., LUNKKA, J.P. \& SARALA, P. 2011. The glaciation of Finland. In EHLERS, J., GIBBARD, P.L. \& HUGHES, P.D. (Eds). Quaternary Glaciations extent and chronology, a closer look. Developments in Quaternary Science. Elsevier, Amsterdam, pp105-116.

Ó COFAIGH, C., PUDSEY, C.J., DOWDESWELL, J.A. \& MORRIS, P. 2002. Evolution of subglacial bedforms along a paleo-ice stream, Antarctic Peninsula continental shelf. Geophysical Research Letters 29, doi:10.1029/2001GL014488.

PUNKARI, M. 1980. The ice lobes of the Scandinavian ice sheet during the deglaciation in Finland. Boreas 9, $307-310$.

STOKES, C.R. \& CLARK, C.D. 2002. Are long subglacial bedforms indicative of fast ice flow? Boreas 31, 239-249.

STROEVEN, A.P., HÄTTESTRAND, C. et al. In press. Deglaciation of Fennoscandia. Quaternary Science Reviews. 
WELLNER, J.S., HEROY, D.C. \& ANDERSON, J.B. 2006. The death mask of the Antarctic Ice Sheet: comparison of glacial geomorphic features across the continental shelf. Geomorphology 75, 157-171.

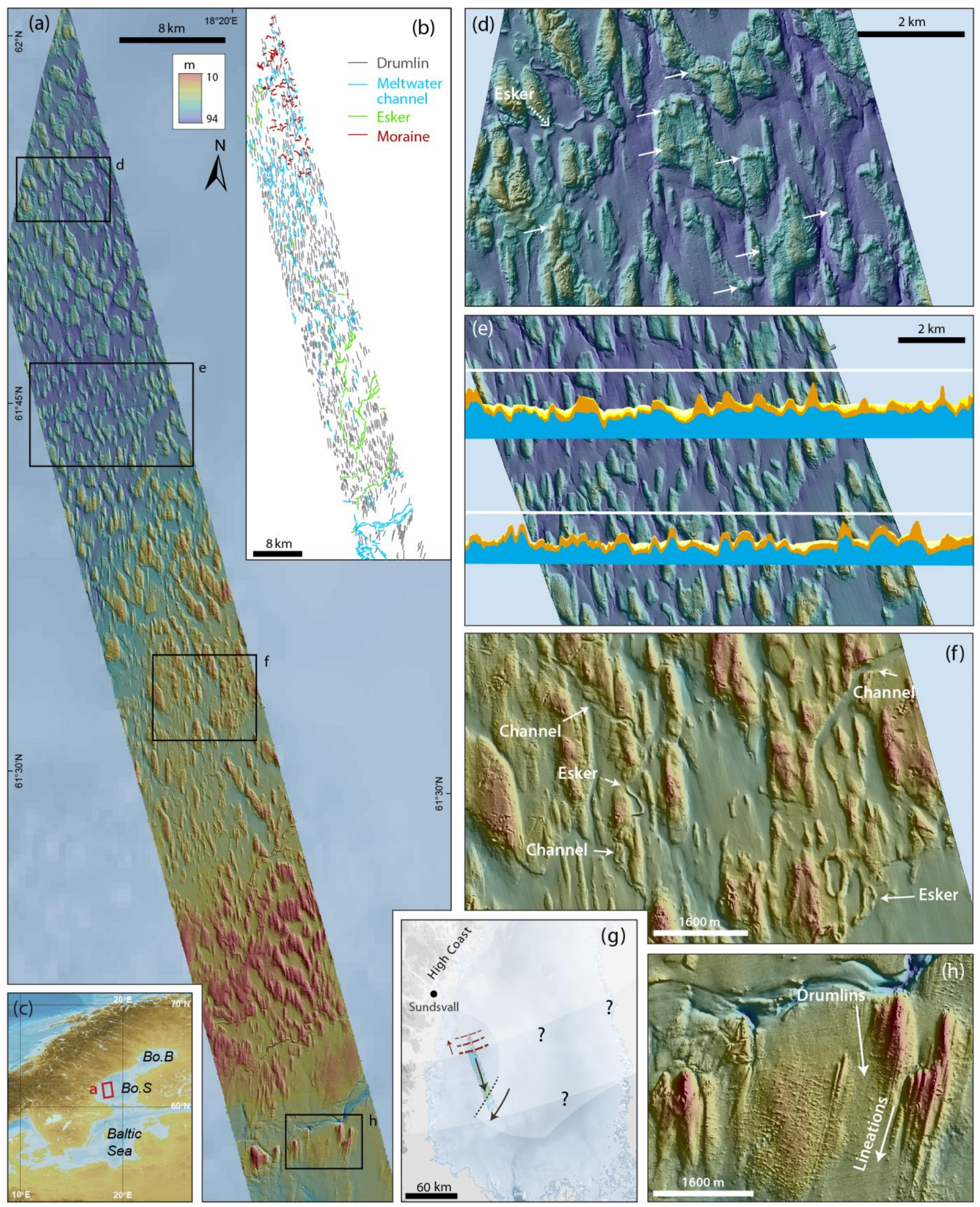

Fig. 1. Assemblage 1, western Bothnian Sea. (a) Multibeam data collected for the Swedish Maritime Administration by FUGRO. Acquisition system Kongsberg EM 2040 , frequency $200-400 \mathrm{kHz}$ in the southern part and Reson $7125 \mathrm{SV}$, frequency $200 / 400 \mathrm{kHz}$ in the north. Grid-cell size $5 \mathrm{~m}$. (b) Landform mapping derived from multibeam data. (c), Study area (red box; map from GEBCO 08). Bo.S = Bothnian Sea and Bo.B = Bothnian Bay, together forming the Gulf of Bothnia. (d) Moraines oriented WSW-ENE (solid white arrows) drape underlying drumlins. (e) Geological Survey of Sweden interpreted seismic profiles show many drumlins are bedrock cored: profile lines in white, with sedimentary bedrock blue, till orange and postglacial sediments in yellow. (f) A well-developed meltwater system drapes/incises drumlins, which are cross-cut at the distal end of the assemblage by spindle-like lineations $(\mathrm{h})$. (g) Palaeo-glacial interpretation of landform assemblage. Black dashed line marks the lateral boundary of distal cross-cutting, and red lines mark retreating margin positions. 

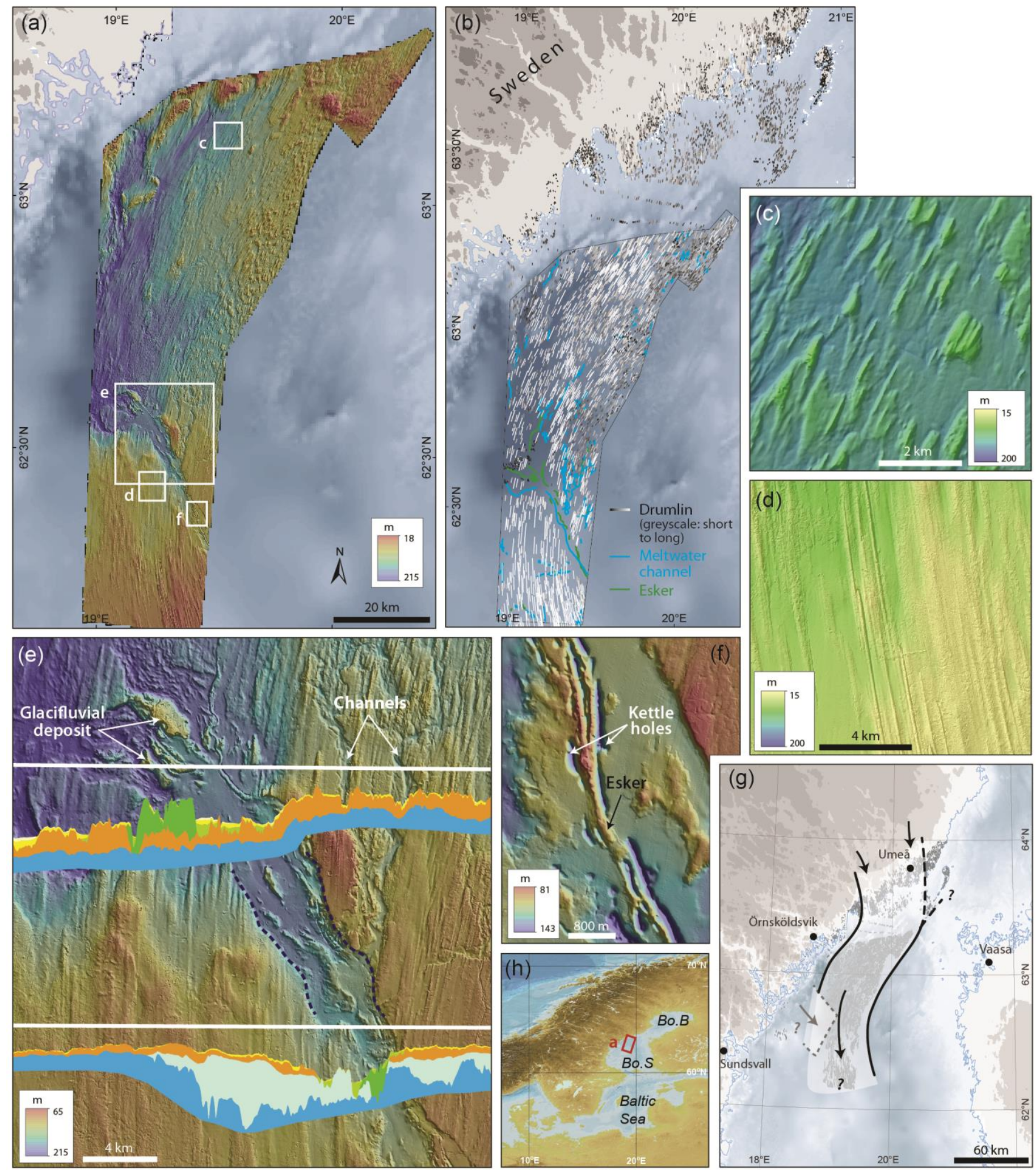

Fig. 2: Assemblage 2, northern Bothnian Sea. (a) Multibeam data collected for the Swedish Maritime Administration by FUGRO. Acquisition system Kongsberg EM 2040 , frequency $200-400 \mathrm{kHz}$ in the southern part and Reson $7125 \mathrm{SV}$, frequency 200/400 kHz in the north. Grid-cell size $5 \mathrm{~m}$. (b) Landform mapping derived from multibeam (coverage outlined), side-scan sonar and terrestrial LiDAR data. Lineations extend downstream from (c) drumlins to (d) MSGLs. (e) A large meltwater system cuts through the lineations. Channels up to $500 \mathrm{~m}$ wide (labelled) feed a $4 \mathrm{~km}$ wide meltwater corridor (dashed lines) that is floored with glacifluvial sediments. Geological Survey interpreted seismic profiles show the corridor cuts through till and pre-last-glacial sediments, while the eastern corridor flank is pinned on a bedrock step (sedimentary bedrock blue, lacustrine sediments pale blue, till orange, glacifluvial sediments green and post-glacial sediments yellow). (f) A small esker and depressions interpreted as kettle holes line the bottom of the meltwater corridor. (g) Interpreted ice stream pathway (from Greenwood et al., 2015). (h) Study area (red box; map from GEBCO_08). Bo.S = Bothnian Sea and Bo.B = Bothnian Bay, together forming the Gulf of Bothnia. 